Published in final edited form as:

Inorg Chem. 2007 October 1; 46(20): 8258-8263. doi:10.1021/ic7008495.

\title{
Sulfoxide as a Ligand in Iron(II) Porphyrinates: S- or O-Bound?
}

\author{
Chuanjiang Hu, Bruce Noll, and W. Robert Scheidt * \\ Contribution from The Department of Chemistry and Biochemistry, University of Notre Dame, Notre \\ Dame, Indiana 46556
}

\begin{abstract}
In order to study the bonding of sulfoxides to iron(II) porphyrinates, an equilibrium study of Fe(TPP) with tetramethylenesulfoxide (TMSO) has been performed. UV-vis spectra at different concentrations of TMSO have shown distinct character belonging to three species: four-coordinate $\mathrm{Fe}(\mathrm{II})(\mathrm{TPP})$, five-coordinate $[\mathrm{Fe}(\mathrm{II})(\mathrm{TPP})(\mathrm{TMSO})]$ and six-coordinate $\left[\mathrm{Fe}(\mathrm{II})(\mathrm{TPP})(\mathrm{TMSO})_{2}\right]$. The isosbestic points for the low TMSO concentrations suggest that the equilibrium constant $\mathrm{K}_{1}$ is much larger than $\mathrm{K}_{2}$. Analysis of spectral data by the nonlinear least-squares program SQUAD gives $\mathrm{K}_{1}$ $=267$ and $K_{2} \approx 1$. Even though the five-coordinate species is the dominant species under the synthetic conditions, only the six-coordinate species was crystallized and characterized by an X-ray diffraction study. [Fe(TPP)(TMSO) $)_{2}$ ] $\left(\mathrm{C}_{52} \mathrm{H}_{44} \mathrm{Fe}-\mathrm{N}_{4} \mathrm{O}_{2} \mathrm{~S}_{2}\right)$ : monoclinic, $P 2_{1} / \mathrm{c}, a=11.2580$ (3) $\AA, b=15.9262$ (5) $\AA, c=12.3930$ (4) $\AA, \beta=116.246(1)^{\circ}, V=1992.95(10) \AA^{3}, Z=2$. X-ray crystallography demonstrates the complex is a low-spin bis-TMSO ligated species. The average $\mathrm{Fe}-\mathrm{N}_{\mathrm{p}}$ distance is 1.999(4) $\AA$. The most important feature is that TMSO is coordinated to iron(II) by the sulfur donors, not oxygen. The Fe-S distance is $2.2220(3) \AA$.
\end{abstract}

\section{Introduction}

The amino acid methionine is a well-known ligand to iron in the ubiquitous electron transfer proteins known as the cytochromes $c$. The other ligand is a histidine. The relative ease of losing methionine coordination has been long recognized and demonstrates the relatively small affinity of a thioether for iron. ${ }^{1}$ Nonetheless, the coordination of the thioether sulfur atom to the physiological oxidation states of cytochrome $c$, that is, iron(II) and iron(III), is clear.

In the presence of reactive oxygen species, methionine can be oxidized to the corresponding sulfoxide. ${ }^{2}$ In mitochondria (a major source of reactive oxygen species ${ }^{3}$ ), oxidation of methionine- 80 to methionine-80 sulfoxide in the protein cytochrome $c$ may occur under normal physiological conditions. Though such a transformation in nature has not been reported, the chemical modification of methionine cytochrome $c$ has been studied and methionine sulfoxide cytochrome $c$ has been shown fully active with cytochrome oxidase. ${ }^{4}$ The heme-binding characteristics of the ligand could be changed when methionine- 80 is modified to methionine-80 sulfoxide in cytochrome $c$. However, the nature of the coordination sphere in methionine-80 sulfoxide cytochrome $c$ was not well established in the previously reported studies.

As an ambidentate ligand, sulfoxides can coordinate to metal ions via sulfur or oxygen. ${ }^{5}$ For methionine sulfoxide cytochrome $c$, an $\mathrm{NMR}^{6}$ study by Ivanetich et al. ${ }^{7}$ suggested the ligand binding is via the sulfur atom in both the ferrous and ferric forms. However, Myer concluded that modification of the methionine to methionine sulfoxide changed the sixth coordination ligand donor atom to heme iron from sulfur to the oxygen of methionine- 80 sulfoxide for both

*To whom correspondence should be addressed. E-mail: scheidt.1@nd.edu. 
iron(II) and iron(III). ${ }^{8}$ They concluded that in the neutral to alkaline $\mathrm{pH}$ range, the low-spin spectrum is a consequence of coordination of heme iron by the sulfoxide oxygen. In recent work on AcMP8, Lushington et al. ${ }^{9}$ suggested that methionine- 80 sulfoxide does not coordinate to iron(III) in the methionine-80 sulfoxide cytochrome $c$ based on the comparison of spectroscopic data for the DMSO complex of Fe(III)-AcMP8 with published data for the methionine-80 sulfoxide form. Their vacuum quantum chemical density functional theory calculations suggested that coordination of DMSO to Fe(II)-AcMP8 via oxygen is enthalpically favored over sulfur coordination; resonance Raman spectroscopic data in aqueous solution concurred with this conclusion. They claimed that the unfavorable steric environment near the heme iron in cytochrome $c$ discriminates against coordination of methionine- 80 sulfoxide.

So it is of fundamental importance to understand the coordination mode of sulfoxide to heme iron. Surprisingly, the interaction of sulfoxide ligand with iron(II) porphyrin has not been directly investigated. This is in distinct contrast to the situation with iron(III) where coordination of sulfoxide through oxygen has been long established. ${ }^{10,11}$ Reed and Scheidt have studied the sulfoxide-ligated iron(III) complex, $\left[\mathrm{Fe}(\mathrm{TPP})(\mathrm{TMSO})_{2}\right] \mathrm{ClO}_{4}$ and the magnetic, Mössbauer, ESR and structure data demonstrate that it is a high-spin O-ligated species. To our knowledge, no structural data on sulfoxide-ligated iron(II) porphyrinates have been reported so far. As part of a more general program of characterization of high-spin iron (II) porphyrinates, ${ }^{12}$ our primary goal was to prepare five-coordinate TMSO-ligated species, but to our surprise, a six-coordinate low-spin S-ligated iron porphyrinate, [Fe(TPP) (TMSO) $)_{2}$, was obtained. We present herein a study of the equilibria of Fe(TPP) with tetramethylenesulfoxide and the molecular structure of [Fe(TPP)(TMSO $\left.)_{2}\right]$.

\section{Experimental Section}

\section{General Information}

Chlorobenzene was washed with concentrated sulfuric acid, then with water until the aqueous layer was neutral, dried with $\mathrm{MgSO}_{4}$, and distilled twice over $\mathrm{P}_{2} \mathrm{O}_{5}$ under argon. Hexanes were distilled over sodium benzophenone. Ethanethiol (Aldrich) was used as received. All other chemicals were used as received from Aldrich or Fisher. meso-Tetraphenylporphyrin $\left(\mathrm{H}_{2} \mathrm{TPP}\right)$ was prepared according to Adler et al. ${ }^{13}$ [Fe(TPP)Cl] was prepared according to a modified Adler preparation; ${ }^{14}[\mathrm{Fe}(\mathrm{TPP})]_{2} \mathrm{O}$ was prepared from $[\mathrm{Fe}(\mathrm{TPP}) \mathrm{Cl}] .{ }^{15}$ All manipulations were performed under argon.

\section{Synthesis of [Fe(TPP)(TMSO) $\left.)_{2}\right]$}

$[\mathrm{Fe}(\mathrm{II})(\mathrm{TPP})]$ was prepared by reduction of $[\mathrm{Fe}(\mathrm{TPP})]_{2} \mathrm{O}(32 \mathrm{mg}, 0.024 \mathrm{mmol})$ with ethanethiol $(\sim 1 \mathrm{~mL})$ in $\sim 6 \mathrm{~mL}$ of chlorobenzene. The chlorobenzene solution was stirred for three days, then transfered into a Schlenk flask containing tetramethylenesulfoxide $(0.5 \mathrm{~mL}, 5.6 \mathrm{mmol})$ by cannula, and stirred for another hour. X-ray quality crystals were obtained in sealed $8 \mathrm{~mm}$ diameter glass tubes by liquid diffiusion using hexanes as the nonsolvent.

\section{Equilibrium Constant Determination}

UV-vis spectra were recorded on a Perkin-Elmer Lambda 19 UV/vis/near-IR spectrometer in a specially designed combined 1- and 10-mm inert atmosphere cell. A solution of the fourcoordinate iron(II) porphyrin was prepared as above. UV-vis spectra of Fe(TPP) in different concentrations of TMSO were measured. For the low concentration region, TMSO was titrated into [Fe(II)(TPP)] in a 5\% EtSH/toluene solution; the EtSH was added to prevent oxidation of the iron. ${ }^{16}$ For the high concentration region, the [Fe(II)(TPP)] solution was added into the concentrated TMSO solution. In order to obtain spectra with appropriate intensity for both the Soret and Q bands, several different concentrations of iron porphyrin were used. The concentrations of TMSO for UV-vis measurements range from $1.13 \times 10^{-3}$ to $10.7 \mathrm{~mol} / \mathrm{L}$. The 
equilibrium constants for these equilibria were calculated with the nonlinear least-squares program SQUAD. ${ }^{17}$ SQUAD calculates best values for the equilibrium constants by employing multiple-wavelength absorption data for varying concentrations of the reactants. Absorbance data, at 10-nm increments spanning the visible region, were input into SQUAD.

\section{X-ray Structure Determinations}

Single crystal experiments were carried out on a Bruker Apex system with graphitemonochromated Mo-K radiation $(\lambda=0.71073 \AA)$. A red crystal with dimensions $0.38 \times 0.33$ $\times 0.20 \mathrm{~mm}^{3}$ was used for the structure determination. The crystalline sample was placed in inert oil, mounted on a glass pin, and transferred to the cold gas stream of the diffractometer. Crystal data were collected at $100 \mathrm{~K}$. The structure was solved by direct methods using SHELXS-97 18 and refined against $\mathrm{F}^{2}$ using SHELXL-97; ${ }^{19,} 20$ subsequent difference Fourier syntheses led to the location of all the remaining non-hydrogen atoms. For the structure refinement all data were used including negative intensities. The structure was refined in space group $\mathrm{P} 2{ }_{1} / \mathrm{c}$. The iron atom is located at a crystallographic inversion center and the asymmetric unit contains half an iron porphyrin and one tetramethylenesulfoxide ligand. All nonhydrogen atoms were refined anisotropically. Hydrogen atoms were added with the standard SHELXL-97 idealization methods. The program SADABS ${ }^{21}$ was applied for the absorption correction. Brief crystal data are listed in Table 1. Complete crystallographic details, atomic coordinates, anisotropic thermal parameters, and hydrogen atom coordinates are given in the Supporting Information.

\section{Results}

Figure 1 shows the UV-vis spectra of Fe(TPP) with TMSO concentrations ranging from 0 to $1.49 \times 10^{-1} \mathrm{~mol} / \mathrm{L}$; the highest concentrations of TMSO are not illustrated. Before the addition of TMSO, the spectrum of $\mathrm{Fe}(\mathrm{II})(\mathrm{TPP})$ shows two Soret bands at 419 and $442 \mathrm{~nm}$ and a relative weaker band at $537 \mathrm{~nm}$ in the $\mathrm{Q}$ band region $(500-700 \mathrm{~nm})$. During the titration, the electronic spectra show that the Soret band becomes a single sharp band at $432 \mathrm{~nm}$ with increased intensity. The band at $537 \mathrm{~nm}$ decreases and new bands show up at 560 and $603 \mathrm{~nm}$. Clear isosbestic points are observed in both Soret and Q band regions. When the concentration of TMSO is over about $0.45 \mathrm{~mol} / \mathrm{L}$, the Soret band begins to decrease and finally shifts to 429 $\mathrm{nm}$ with a relatively weaker intensity in $10.7 \mathrm{~mol} / \mathrm{L}$ of TMSO (95\%). The bands at 560 and $603 \mathrm{~nm}$ decrease and the band at $530 \mathrm{~nm}$ increases by the increasing of TMSO concentration.

Crystals were obtained from solutions where the TMSO to Fe(TPP) concentration ratio was $\sim 220$. X-ray crystallography shows that the isolated complex is a six-coordinate species. An ORTEP diagram is provided in Figure 2, and selected bond distances and angles are listed in Table 2. The porphyrin molecule has inversion symmetry, the iron(II) atom is at an inversion center and coordinated to four pyrrole nitrogens and two sulfur atoms of tetramethylenesulfoxide. The average $\mathrm{Fe}-\mathrm{N}_{\mathrm{p}}$ distance is 1.999(4) $\AA$ and the $\mathrm{Fe}-\mathrm{S}$ distance is 2.2220(3) A. Coordination at the sulfur atom is pyramidal, with an O-S-C bond angle of 106.54 $(7)^{\circ}$, a C-S-C angle of $91.76(7)^{\circ}$, a Fe-S-O angle of $118.91(5)^{\circ}$; and an average $\mathrm{Fe}-\mathrm{S}-\mathrm{C}$ angle of $114.7(6)^{\circ}$. The $\mathrm{S}-\mathrm{O}$ distance is $1.4794(11) \AA$. A complete listing of bond distances and angles is given in the Supporting Information.

The displacement of each atom of the porphyrin core from the 24-atom mean plane is shown in Figure 3. Also included on the diagrams of Figure 3 are the individual $\mathrm{Fe}-\mathrm{N}_{\mathrm{p}}$ bond lengths. An analogous diagram showing atomic displacements from the mean plane of the four pyrrole nitrogen atoms is given in Figure $\mathrm{S} 1$ of the supporting information. 


\section{Discussion}

\section{Spectral Studies}

There are three species involved in the reaction of TMSO with Fe(II)(TPP): four-coordinate $\mathrm{Fe}(\mathrm{II})(\mathrm{TPP})$, five-coordinate [Fe(II)(TPP)(TMSO)] and six-coordinate [Fe(II)-(TPP) $\left.(\mathrm{TMSO})_{2}\right]$.

$$
\begin{gathered}
\mathrm{Fe}(\mathrm{II})(\mathrm{TPP})+\mathrm{TMSO} \stackrel{K_{1}}{\rightleftharpoons} \mathrm{FE}(\mathrm{II})(\mathrm{TPP})(\mathrm{TMSO}) \\
\mathrm{Fe}(\mathrm{II})(\mathrm{TPP})(\mathrm{TMSO})+\mathrm{TMSO} \stackrel{K_{2}}{\rightleftharpoons} \mathrm{FE}(\mathrm{II})(\mathrm{TPP})(\mathrm{TMSO})_{2}
\end{gathered}
$$

Because the iron(II) porphyrinates with different coordination number have substantially different absorption spectra, ${ }^{22} \mathrm{UV}$-vis spectroscopy can be used to monitor the reaction and determine the equilibrium constants. As shown in Figures 1 and 4, both the Soret band and Q bands show remarkable changes during the titration. The spectrum with TMSO concentration at $4.3 \times 10^{-2} \mathrm{~mol} / \mathrm{L}$ shows a sharp Soret band at $432 \mathrm{~nm}$ and three bands in the $\mathrm{Q}$ band region: two broad bands with similar intensities at around 540 and $555 \mathrm{~nm}$ and one at $603 \mathrm{~nm}$ with about half the intensity of the other two bands. This spectral pattern, including intensity, is similar to that observed for imidazole-ligated five-coordinate high-spin iron(II) species. ${ }^{22} \mathrm{We}$ can thus conclude that the dominant species in this solution is a five-coordinate high-spin species. Analysis by the SQUAD program suggests [Fe(TPP)(TMSO)] is $89 \%$ of the total iron species at this concentration. The spectrum in $10.7 \mathrm{~mol} / \mathrm{L} \mathrm{TMSO}$ is substantially different. The single Soret band is shown at a similar position with lower intensity. The $\mathrm{Q}$ bands show distinct differences in extinction coefficients: the major peak at $530 \mathrm{~nm}$ is about twice as intense as the shoulder peak at $560 \mathrm{~nm}$. These features are the same as features observed in the six-coordinate nitrogen based species, ${ }^{22}$ which suggests the dominant species in this solution is six-coordinate low-spin [Fe(TPP)(TMSO) 2 ]. Analysis by the SQUAD program confirms [Fe(TPP) $\left.(\mathrm{TMSO})_{2}\right]$ is $91 \%$ of the total iron species at this concentration. Values of the extinction coefficients are calculated by the SQUAD program: $\lambda_{\max }(\log \varepsilon): 432(5.38), 540(4.03), 560$ (4.03), 603(3.61) for [Fe(TPP)(TMSO)]; 429(5.16), 530 (4.13), 560(3.96) for [Fe(TPP) $\left.(\mathrm{TMSO})_{2}\right]$.

The spectral changes in Figure 1 suggests that they relate to reaction 1. The appearance of isosbestic points indicates only one major species formed at these concentrations, a fivecoordinate species. It also suggests that the equilibrium constant $\mathrm{K}_{1}$ is much larger than $\mathrm{K}_{2}$. The analysis of the spectral data by the SQUAD program supports this. The result gives formation constants $\log \mathrm{K}_{1}=2.43 \pm 0.06$ and $\log \beta_{2}=\log \left(\mathrm{K}_{1} \mathrm{~K}_{2}\right)=2.41 \pm 0.16$. This gives $\mathrm{K}_{1}$ $=267$ and $\mathrm{K}_{2}=0.95$. A value of $\mathrm{K}_{2} \approx 2300$ has been reported from a photolysis experiment. 23 It is likely that the equilibrium constant (in pure TMSO) is actually that of $\mathrm{K}_{1}$.

All the above suggests three species in solution are dominant at different concentrations of TMSO. Six-coordinate $\left[\mathrm{Fe}(\mathrm{TPP})(\mathrm{TMSO})_{2}\right]$ is the dominant species in solution at very high concentrations of TMSO, while five-coordinate species is the dominant species at relative low concentrations. In order to prepare a five-coordinate species, the synthesis was performed at $0.75 \mathrm{~mol} / \mathrm{L}$ of TMSO. At that concentration, the dominant species in solution is five-coordinate [Fe(TPP)(TMSO)]. But the six-coordinate species was crystallized and verified by X-ray crystallography. Its crystallization is probably due to solubility issues even though it is not the major species in solution. Finally, it should be noted that our spectroscopic data do not define the coordination modes ( $\mathrm{O}$ versus $\mathrm{S}$ ) nor that in a mixed ligand complex such as a nitrogen donor/sulfoxide that iron(II) would definitely be coordinated by the sulfur. 


\section{Molecular Structure}

In the crystal structure, the average $\mathrm{Fe}-\mathrm{N}_{\mathrm{p}}$ distance in $\left[\mathrm{Fe}(\mathrm{TPP})-(\mathrm{TMSO})_{2}\right]$ is $1.999(4) \AA$. This distance is that expected for a low-spin iron(II) species. ${ }^{24}$ Low-spin iron(II) examples for comparison include a thioether-ligated species: [Fe(TPP)(THT) $\left.)_{2}\right](1.996(6) \AA),{ }^{25}$ several imidazole-ligated species: [Fe(TPP)(1-VinIm) 2 ] (2.001(2) ̊̊), [Fe(TPP)(1-BzylIm) $)_{2}$ ] $(1.993$ (9) $\AA$ ) $\left[\mathrm{Fe}(\mathrm{TPP})(1-\mathrm{MeIm})_{2}\right](1.997(6) \AA) 26$ and several pyridine-ligated species: [Fe(TMP) $\left.(4-\mathrm{CNPy})_{2}\right]$ (1.992(1) A), [Fe(TMP)(3-CNPy $\left.)_{2}\right](1.996(0) \AA),\left[\mathrm{Fe}(\mathrm{TMP})(4-\mathrm{MePy})_{2}\right] 1.988(0)$ $\AA$ А). ${ }^{27}$

The low-spin state of $\left[\mathrm{Fe}(\mathrm{TPP})(\mathrm{TMSO})_{2}\right]$ is in distinct contrast to the bis(sulfoxide) complexes of iron(III) porphyrinates that are all known to be high spin. ${ }^{10,11}$ The significant difference between the iron(II) and iron(III) porphyrinate systems is the ligation mode of the sulfoxide ligands: O-bound in iron(III) and S-bound in iron(II). Qualitatively, such a difference in axial coordination mode could be predicted by Pearson's HSAB principles. ${ }^{28}$ The harder iron(III) is expected to bind the hard oxygen donor atom of the sulfoxide, consistent with observation. Iron(II), on the other hand, is considered a borderline acid and either O- or S-ligated sulfoxide species might be anticipated. Indeed, both O-bound 29,30 and S-bound, 31,32 sulfoxide complexes of iron(II) are known. However, the "hardness" and "softness" of a metal ion can be dramatically modified by the nature of the other ligands, depending on their s-donating or p-accepting properties. ${ }^{33,} 34$ For the case of porphyrin derivatives, the highly delocalized $p$ system will tend to make iron(II) softer and favor sulfur ligation as observed.

Most oxygen-ligated iron(II) porphyrinates are species with THF or alcohol as the axial ligands. 35-39 Contrasting with the aforementioned low-spin S-ligated iron(II) porphyrinates, their central irons are in the high-spin state with an expanded porphyrin core as shown in Table 3.

As can be seen in the Figure 3, the porphyrin core is very planar. The $\mathrm{S}-\mathrm{O}$ bond is close to eclipsing the $\mathrm{N}(1) \mathrm{N}\left(1^{\prime}\right)$ direction, $\left(\mathrm{N}\left(1^{\prime}\right)\right.$ is a symmetry related pyrrole nitrogen of $\left.\mathrm{N}(1)\right)$ the angle between the projection of the $\mathrm{S}-\mathrm{O}$ bond and the $\mathrm{Fe}-\mathrm{N}_{\mathrm{p}}$ vector is $5.8^{\circ}$. The orientation is also illustrated in Figure 3.

The six-coordinate and S-ligation state of [Fe(TPP)(TMSO $\left.)_{2}\right]$ is clearly seen in Figure 2. Scheidt and Reed had noted earlier that the $\mathrm{Fe}-\mathrm{S}$ distances in a wide variety of iron porphyrinate derivatives was insensitive to a number of factors that could be expected to lead to differing FeS distances: all observed distances are $\sim 2.35 \AA$. The relatively short $\mathrm{Fe}-\mathrm{S}$ distance of 2.2220 (3) $\AA$ in $\left[\mathrm{Fe}(\mathrm{TPP})(\mathrm{TMSO})_{2}\right]$ was therefore rather unexpected and can be compared to 2.338

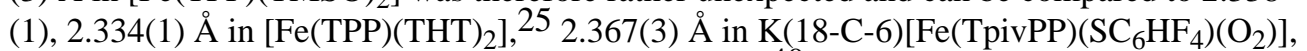
2.365(2) $\AA$ in $\mathrm{Na}(18-\mathrm{C}-6)\left[\mathrm{Fe}(\mathrm{TpivPP})\left(\mathrm{SC}_{6} \mathrm{HF}_{4}\right)\left(\mathrm{O}_{2}\right)\right],{ }^{40} 2.324(2) \AA$ in $\mathrm{Na}(222)[\mathrm{Fe}(\mathrm{TpivPP})$ $\left.\left(\mathrm{SC}_{2} \mathrm{H}_{5}\right)\right]^{41}$ and 2.380(2) $\AA$ in $\mathrm{K}(222)\left[\mathrm{Fe}(\mathrm{TpivPP})(\mathrm{PMS})\left(\mathrm{NO}_{2}\right)\right] .{ }^{42}$ It is thus seen that the $\mathrm{Fe}-$ $\mathrm{S}$ distance in $\left[\mathrm{Fe}(\mathrm{TPP})(\mathrm{TMSO})_{2}\right]$ is more than $0.1 \AA$ shorter than all previously observed $\mathrm{Fe}^{\mathrm{II}}-\mathrm{S}$ distances. A similar situation has been seen in ruthenium(II) porphyrinates, although the difference between $\mathrm{Ru}-\mathrm{S}$ distances in the S-ligated sulfoxide and thioether complexes is about $0.05 \AA$. The observed distances are $\mathrm{Ru}-\mathrm{S}=2.319(1) \AA$ in $\left[\mathrm{Ru}(\mathrm{II})(\mathrm{OEP})(\mathrm{DMSO})_{2}\right],{ }^{4}$ and 2.376(1) $\AA$ and 2.371(1) $\AA$ in $\left[\mathrm{Ru}(\mathrm{OEP})(\mathrm{DecMS})_{2}\right]$ and $\left[\mathrm{Ru}(\mathrm{OEP})\left(\mathrm{SPh}_{2}\right)_{2}\right],{ }^{44}$ respectively.

The shortening of the $\mathrm{Fe}-\mathrm{S}$ bond in the S-bound sulfoxides relative to analogous thioether derivatives can be associated with either a strengthening of $\mathrm{Fe}-\mathrm{S} \mathrm{d} \mathrm{d}_{\pi}-\mathrm{p}_{\pi}$ back-bonding, enhanced $\sigma$-bonding or possible steric effects. Steric effects appear to have no influence as nonbonded distances between the TMSO ligand or the tetrahydrothiophene ligand and the porphyrin in the respective six-coordinate complexes are similar. Increased $\pi$-back-bonding has been proposed for $\mathrm{Ru}$ (II)-DMSO nonporphyrin complexes; $5,45,46$ such $\pi$ bonding is associated with a lengthening of the $\mathrm{S}-\mathrm{O}$ bond relative to the value in uncomplexed sulfoxides. However in $\left[\mathrm{Fe}(\mathrm{TPP})(\mathrm{TMSO})_{2}\right]$, the $\mathrm{S}-\mathrm{O}$ distance $(1.4794(11) \AA)$ is close to that in free tetramethylene- 
sulfoxide (1.484(3) ̊̊). 47 Thus, $\pi$ back-bonding does not appear to be making a significant contribution to the shortness of the $\mathrm{Fe}-\mathrm{S}$ bond in $\left[\mathrm{Fe}(\mathrm{TPP})(\mathrm{TMSO})_{2}\right]$. Enhanced $\sigma$-bonding of the TMSO is the most possible reason for the shortening of the $\mathrm{Fe}-\mathrm{S}$ bond. If there is enhanced $\sigma$-bonding in TMSO complexes, the TMSO will be expected to be more basic than tetrahydrothiophen which has been observed. ${ }^{48}$ This enhanced $\sigma$-bonding has also been suggested by Lushington et al. ${ }^{9}$ in a DFT calculation.

\section{Summary}

A study of the equilibria of Fe(TPP) with tetramethylenesulfoxide (TMSO) has been performed. Equilibrium constants were obtained as $\mathrm{K}_{1}=267$ and $\mathrm{K}_{2}=0.95$. At low concentration, the spectra show isosbestic points during the titration. Three species in solution are dominant at different TMSO concentrations. Under the synthetic conditions, the dominant species in solution is five-coordinate species. But probably due to solubility issues, the sixcoordinate species, $\left[\mathrm{Fe}(\mathrm{II})(\mathrm{TPP})(\mathrm{TMSO})_{2}\right]$, was crystallized. X-ray crystallography shows that is a sulfur-ligated low-spin species, not like the oxygen-ligated high-spin [Fe(III)(TPP) $(\mathrm{TMSO})_{2} \mathrm{CClO}_{4}$. The average $\mathrm{Fe}-\mathrm{N}_{\mathrm{p}}$ distance (1.999(4) $\AA$ ) and the $\mathrm{Fe}-\mathrm{S}$ distance $(2.2220(3)$ $\AA$ A).

\section{Supplementary Material}

Refer to Web version on PubMed Central for supplementary material.

\section{Acknowledgements}

We thank the National Institutes of Health for support of this research under Grant GM-38401. W.R.S. thanks Professor Kenton R. Rodgers for a useful discussion.

\section{References and Notes}

1. Taler G, Schejter A, Navon G, Vig I, Margoliash E. Biochemistry 1995;34:14209. [PubMed: 7578019]

2. Gilbert, DL.; Colton, CA., editors. Reactive Oxygen Species in Biological Systems. Kluwer Academic/ Plenum; New York: 1999.

3. Funkel T, Holbrook NJ. Nature 2000;408:239. [PubMed: 11089981]

4. Ivanetich KM, Bradshaw JJ, Kaminsky LS. Biochemistry 1976;15:1144. [PubMed: 3210]

5. Calligaris M, Carugo O. Coord Chem Rev 1996;153:83.

6. The following abbreviations are used in this paper: NMR, nuclear magnetic resonance; AcMP8, Nacetylmicroperoxidase-8; TPP, dianion of meso-tetraphenylporphyrin; TpivPP, dianion of $\alpha, \alpha, \alpha, \alpha$ tetrakis (o-pivalamidophenyl)porphyrin; $\mathrm{TDCP}\left(\mathrm{NO}_{2}\right)_{8} \mathrm{P}$, di-anion of meso-tetrakis $(o$ dichlorophenyl)- $\beta$-octanitroporphyrin; PPIX, dianion of protoporphyrin IX; $\mathrm{N}_{\mathrm{p}}$, porphyrinato nitrogen; TMSO; tetramethylenesulfoxide; THT, tetrahydrothiophen; PMS, pentamethylene sulfide; THF, tetrahydrogenfuran; EtOH, ethanol; PrOH, propanol; DMSO, dimethylsulfoxide; DecMS, thioethers $n$-decylmethyl sulfide; $\mathrm{SPh}_{2}$, diphenyl sulfide; 1-MeIm, 1-methylimidazole; 1-VinIm, 1vinylimidazole; 1-BzylIm, 1-benzylimidazole; 4-CNPy, 4-cyanopyridine; 3-CNPy, 3-cyanopyridine; 4-MePy, 4-methylpyridine; Pc, phthalocyanine; HSAB, Hard-Soft-Acid-Base; ESR, electronic spin resonance; 18-C-6, 1,4,7,10,13,16-hexaoxacyclooctadecane; 222, 1,10-diaza-4,7,13,16,21,24hexaoxabicyclo[8.8.8]hexacosane.

7. Ivanetich KM, Bradshaw JJ, Fazakerley GV. Biochem Biophys Res Com 1976;72:433. [PubMed: 10905]

8. Myer YP, Kumar S, Kinnally K, Pande J. J Protein Chem 1987;6(4):321.

9. Lushington GH, Cowley AB, Silchenko S, Lukat-Rodgers GS, Rodgers KR, Benson DR. Inorg Chem 2003;42:7550. [PubMed: 14606851]

10. Mashiko T, Kastner ME, Spartalian K, Scheidt WR, Reed CA. J Am Chem Soc 1978;100:6354. 
11. Muthusamy M, Andersson LA, Sun J, Loehr TM, Thomas CS, Sullivan EP Jr, Thomson MA, Long KM, Anderson OP, Strauss SH. Inorg Chem 1995;34:3953.

12. Hu C, Roth A, Ellison MK, An J, Ellis CM, Schulz CE, Scheidt WR. J Am Chem Soc 2005;127:5675. [PubMed: 15826208]

13. Adler AD, Longo FR, Finarelli JD, Goldmacher J, Assour J, Korsakoff L. J Org Chem 1967;32:476.

14. (a) Adler AD, Longo FR, Kampus F, Kim J. J Inorg Nucl Chem 1970;32:2443.Buchler, JW.

Porphyrins and Metalloporphyrins. Smith, KM., editor. Elsevier Scientific Publishing; Amsterdam, The Netherlands: 1975. Chapter 5

15. (a) Fleischer EB, Srivastava TS. J Am Chem Soc 1969;91:2403. (b) Hoffman AB, Collins DM, Day VW, Fleischer EB, Srivastava TS, Hoard JL. J Am Chem Soc 1972;94:3620. [PubMed: 5032963]

16. Even under these dilute solution conditions, we see no spectral changes resulting from the presence of EtSH and we conclude that EtSH does not coordinate to iron. The relatively long times of the titrations do require EtSH.

17. Leggett, DJ. Computational Methods for the Determination of Formation Constants. Leggett, DJ., editor. Plenum; New York: 1985. Chapter 6

18. Sheldrick GM. Acta Crystallogr 1990;A46:467.

19. Sheldrick, GM. Program for the Refinement of Crystal Structures. Universität Göttingen; Germany: 1997.

20. $\mathrm{R}_{1}=\Sigma|| \mathrm{F}_{\mathrm{o}}|-| \mathrm{F}_{\mathrm{c}} \| / \Sigma\left|\mathrm{F}_{\mathrm{o}}\right|$ and $\mathrm{wR}_{2}=\left\{\Sigma\left[\mathrm{w} \mathrm{F}_{\mathrm{o}}{ }^{2}-\mathrm{F}_{\mathrm{c}}{ }^{2}\right)^{2} / \Sigma\left[\mathrm{wF}_{\mathrm{o}}^{4}\right]\right\}^{1 / 2}$. The conventional R-factors $\mathrm{R}_{1}$ are based on $\mathrm{F}$, with $\mathrm{F}$ set to zero for negative $\mathrm{F}^{2}$. The criterion of $\mathrm{F}^{2}>2 \sigma\left(\mathrm{F}^{2}\right)$ was used only for calculating $\mathrm{R}_{1}$. R-factors based on $\mathrm{F}^{2}\left(\mathrm{wR}_{2}\right)$ are statistically about twice as large as those based on $\mathrm{F}$, and R-factors based on ALL data will be even larger.

21. Sheldrick, GM. Program for Empirical Absorption Correction of Area Detector Data. Universität Göttingen; Germany: 1996.

22. Collman JP, Brauman JI, Doxsee KM, Halbert TR, Bumenberg E, Linder RE, LaMar GN, Del Gaudio J, Lang G, Spartalian K. J Am Chem Soc 1980;102:4182.

23. Larsen RW, Wheeler PE, Findsen EW. Inorg Chim Acta 2001;319:1.

24. Scheidt WR, Reed CA. Chem Rev 1981;81:543.

25. Mashiko T, Reed CA, Haller KJ, Kastner ME, Scheidt WR. J Am Chem Soc 1981;103:5758.

26. Safo MK, Scheidt WR, Gupta GP. Inorg Chem 1990;29:626.

27. Safo MK, Nesset MJM, Walker FA, Debrunner PG, Scheidt WR. J Am Chem Soc 1997;119:9438.

28. Pearson RG. Coord Chem Rev 1990;100:403.

29. Lippard SJ, Carson EC. Inorg Chem 2006;45:837. [PubMed: 16411722]

30. Muller A, Bogge H, Schimanski U, Penk M, Nieradzik K, Dartmann M, Krickemeyer E, Schimanski J, Romer C, Romer M, Dornfeld H, Wienboker U, Hellmann W, Zimmermann M. Monatsh Chem 1989;120:367.

31. Calderazzo F, Pampaloni G, Vitali D, Collamati I, Dessy G, Fares V. J Chem Soc, Dalton Trans 1980:1965-1969.

32. Carni C, Pelizzi C, Pelizzi G, Predieli G, Tarasconi P, Vitali F. J Chem Soc Chem Commun 1990:613.

33. Alessio E, Milani B, Bolle M, Mestroni G, Faleschini P, Todone F, Geremia S, Calligaris M. Inorg Chem 1995;34:4722.

34. Calligaris M, Faleschini P, Todone F, Alessio E, Geremia S. J Chem Soc Dalton Trans 1995:1653.

35. Ohgo Y, Saitoh T, Nakamura M. Acta Cryst C 2001;57:233. [PubMed: 11250558]

36. Reed CA, Mashiko T, Scheidt WR, Spartalian K, Lang G. J Am Chem Soc 1980;102:2302.

37. Thompson DW, Kretzer RM, Lebeau EL, Scaltrito DV, Ghiladi RA, Lam KC, Rheingold AL, Karlin KD, Meyer GJ. Inorg Chem 2003;42:5211. [PubMed: 12924892]

38. Hu C, Noll BC, Scheidt WR. Acta Cryst E 2005;E61:m830.

39. Barkigia KM, Palacio M, Sun Y, Nogues M, Renner MW, Varret F, Battioni P, Mansuy D, Fajer J. Inorg Chem 2002;41:5647. [PubMed: 12401065]

40. Schappacher M, Ricard L, Fischer J, Weiss R, Bill E, Montiel-Montoya R, Trautwein AX. Eur J Biochem 1987;168:419. [PubMed: 3665929] 
41. Schappacher M, Ricard L, Fischer J, Weiss R, Montiel-Montoya R, Bill E, Trautwein AX. Inorg Chem 1989;28:4639.

42. Nasri H, Ellison MK, Krebs C, Huynh BH, Scheidt WR. J Am Chem Soc 2000;122:10795.

43. Pacheco A, James BR, Rettig SJ. Inorg Chem 1999;38:5579. [PubMed: 11671286]

44. James BR, Pacheco A, Rettig SJ, Ibers JA. Inorg Chem 1988;27:2414.

45. Davies JA. Adv Inorg Chem Radiochem 1981;24:115.

46. March FC, Ferguson G. Can J Chem 1971;49:3590.

47. Forgács G, Schultz G I, Hargittai I, Jalsovszky I, Kucsman A. J Chem Soc, Faraday Trans 2 1989;85:303.

48. Curci R, Di Furia F, Levi A, Lucchini V, Scorrano G. J C S Perkin II 1975:341. 


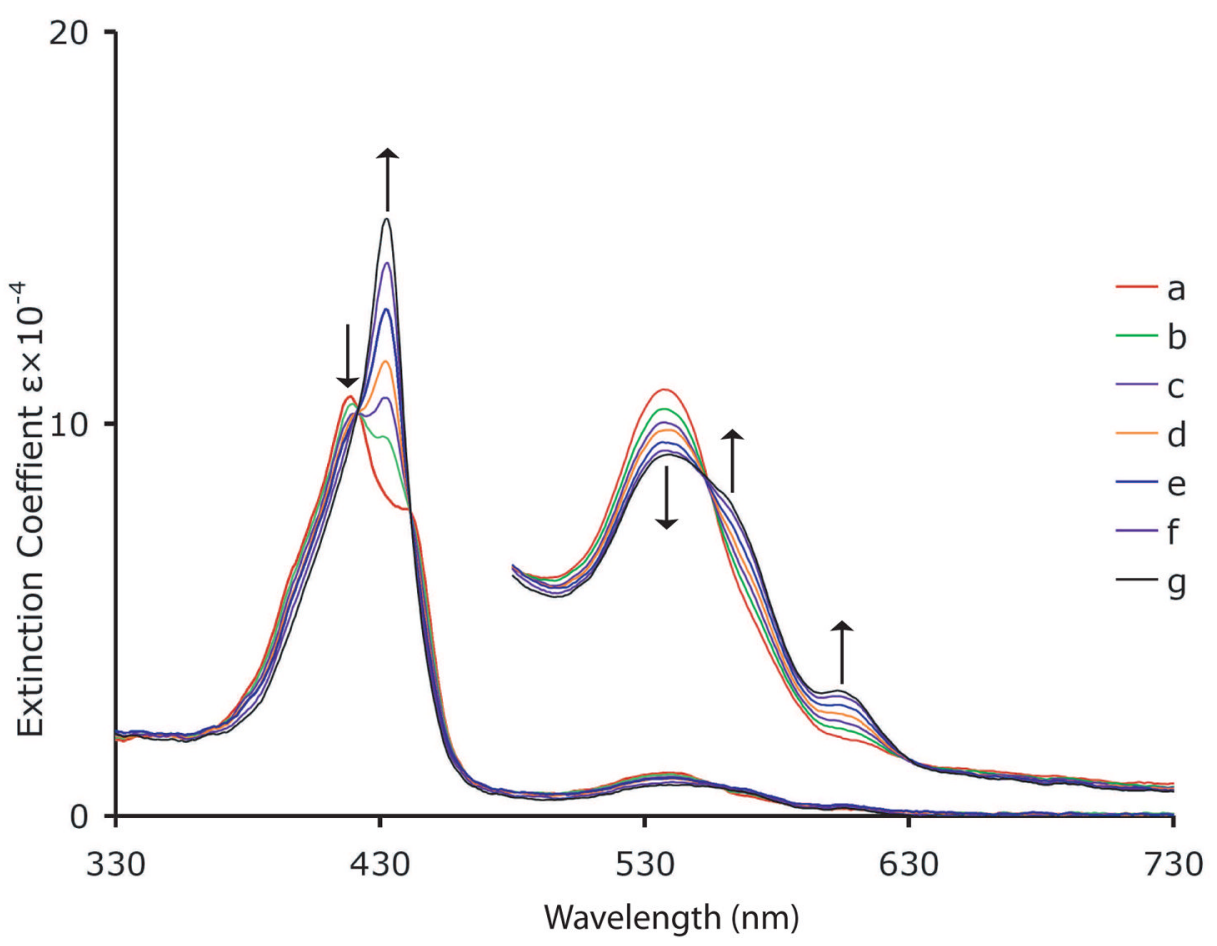

Figure 1.

UV-vis spectra taken under argon in 5\% EtSH/toluene solution. Concentration of [Fe(TPP)] is $0.86 \times 10^{-4} \mathrm{~mol} / \mathrm{L}$, TMSO concentrations in $\left.10^{-3} \mathrm{~mol} / \mathrm{L} \mathrm{a}\right) 1.13$. b) 2.26 . c) 3.39 . d) 5.08 . e) 7.23. f) 9.95 g) 14.2 . The enlarged spectra from 480 to $730 \mathrm{~nm}$ are measured in the $10-\mathrm{mm}$ UV cell. 


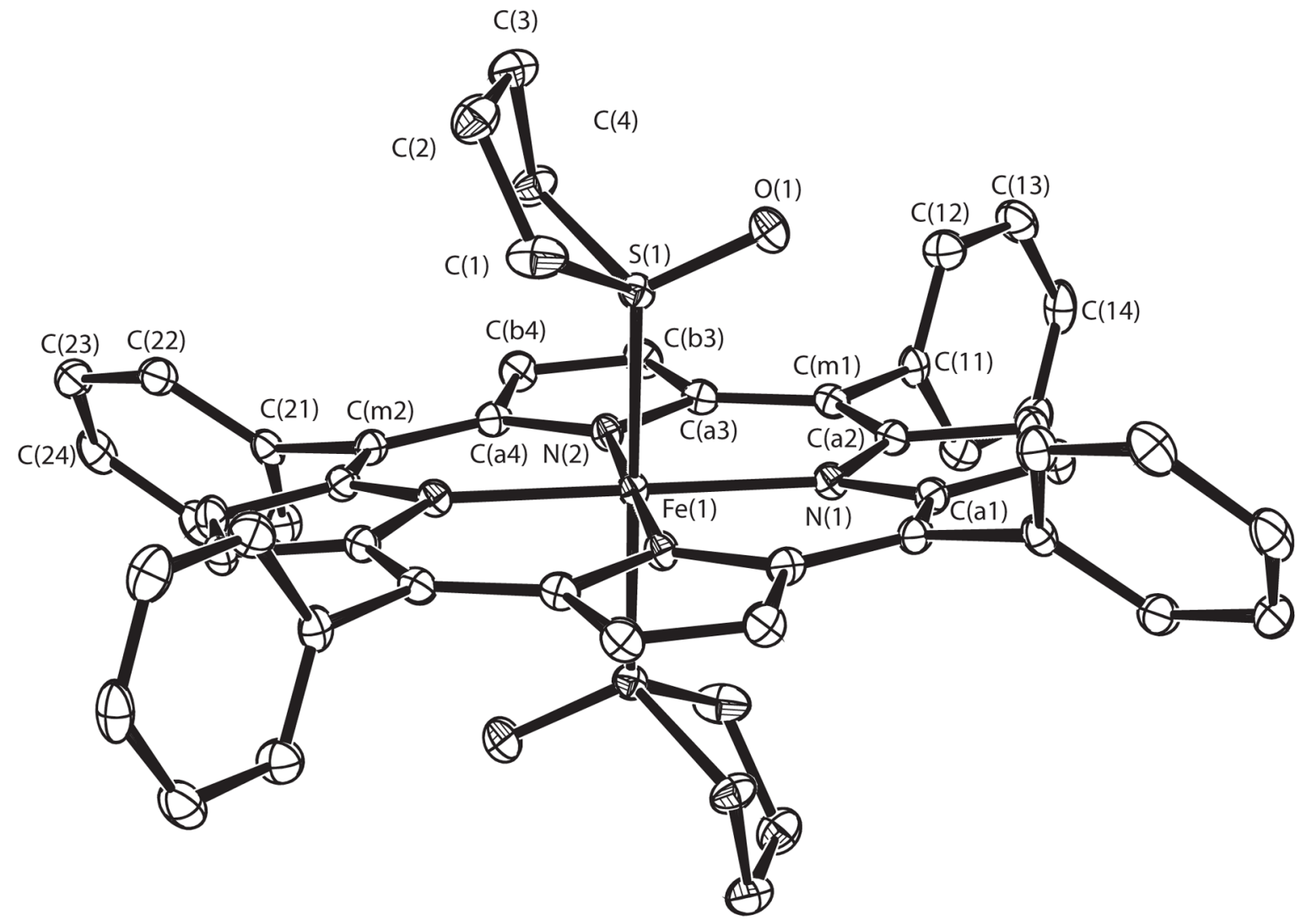

Figure 2.

ORTEP diagram of [Fe(TPP)(TMSO $\left.)_{2}\right]$. The hydrogen atoms of the porphyrin ligand have been omitted for clarity. $50 \%$ probability ellipsoids are depicted. 


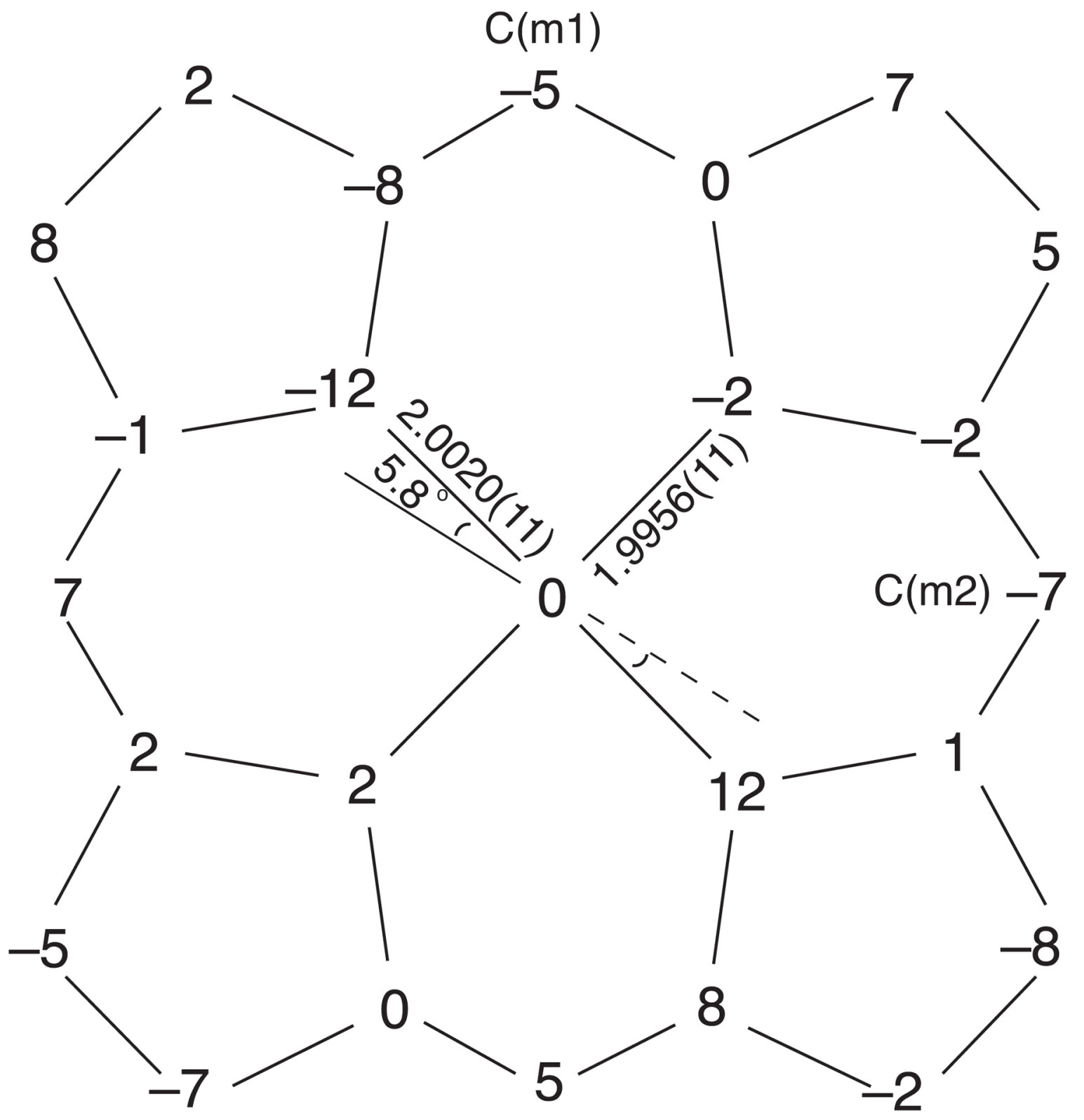

Figure 3.

Diagrams illustrating the core conformation and iron displacement of the title complex. The displacement of the iron and the atoms of the porphyrin core from the mean plane defined by the twenty four porphyrin atoms is given. The position of the $\mathrm{S}-\mathrm{O}$ bond with respect to directions defined by the $\mathrm{Fe}-\mathrm{N}_{\mathrm{p}}$ directions is shown: solid line means above the plane, dash line means below the plane. 


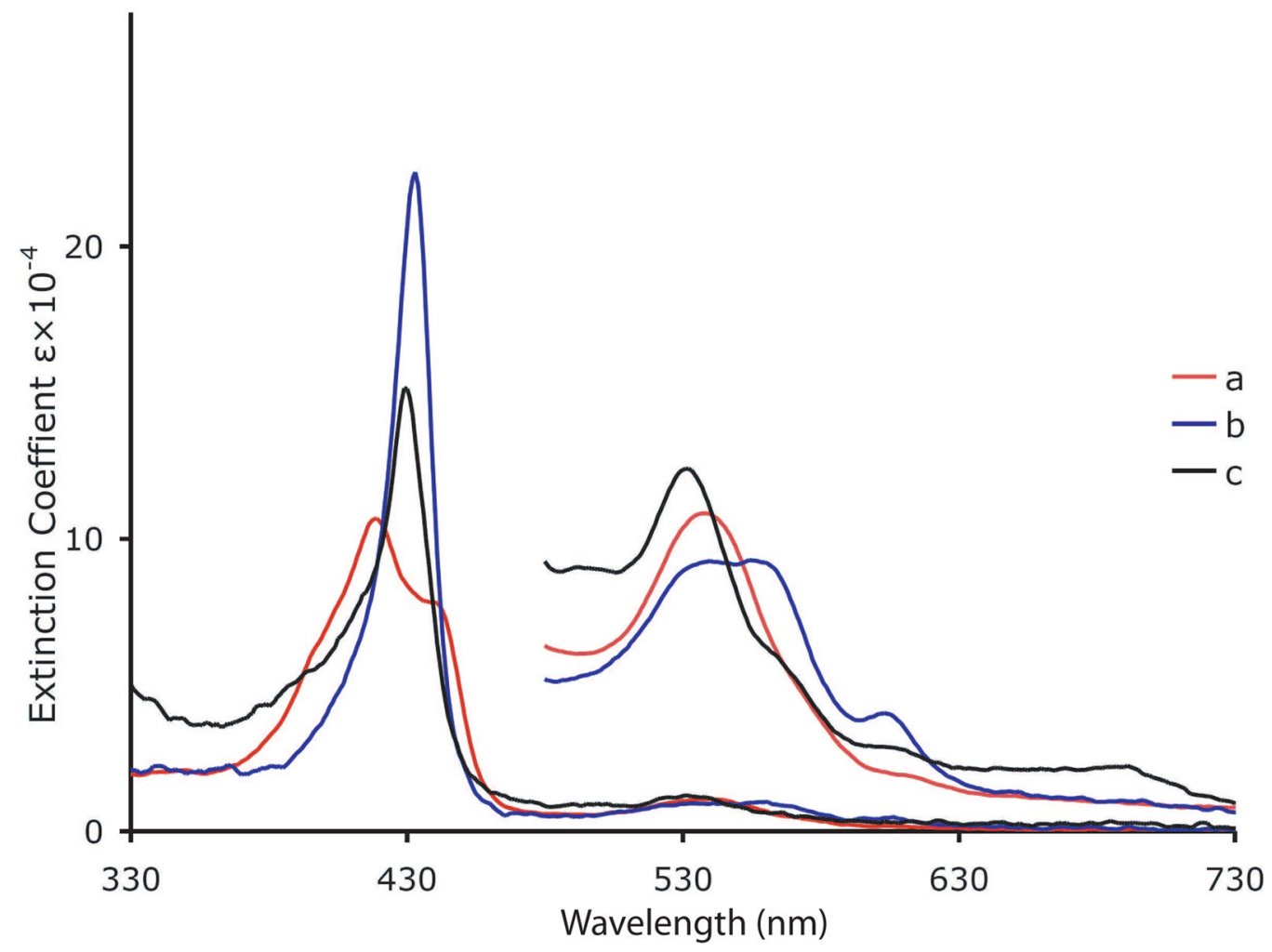

Figure 4.

UV-vis spectra taken under argon. a) $\left.\mathrm{Fe}(\mathrm{II})(\mathrm{TPP})\left(8.6 \times 10^{-5} \mathrm{~mol} / \mathrm{L}\right) \mathrm{b}\right) \mathrm{Fe}(\mathrm{II})(\mathrm{TPP})(3.8 \times$ $\left.10^{-5} \mathrm{~mol} / \mathrm{L}\right)$ in $4.3 \times 10^{-2} \mathrm{~mol} / \mathrm{L}$ TMSO solution. c) $\mathrm{Fe}(\mathrm{II})(\mathrm{TPP})\left(3.0 \times 10^{-5} \mathrm{~mol} / \mathrm{L}\right)$ in 10.7 $\mathrm{mol} / \mathrm{L}$ TMSO solution. The enlarged spectra from 480 to $730 \mathrm{~nm}$ are measured in the $10-\mathrm{mm}$ UV cell. 
Table 1

Brief Crystallographic Data and Data Collection Parameters for [Fe(TPP)(TMSO) 2 ].

\begin{tabular}{|c|c|}
\hline Formula & $\mathrm{C}_{52} \mathrm{H}_{44} \mathrm{FeN}_{4} \mathrm{O}_{2} \mathrm{~S}_{2}$ \\
\hline $\mathrm{FW}$, amu & 876.88 \\
\hline$a, \AA$ & $11.2580(3)$ \\
\hline$b, \AA$ & $15.9262(5)$ \\
\hline$c, \AA$ & $12.3930(4)$ \\
\hline$\beta$, deg & $116.246(1)$ \\
\hline$V, \AA^{\xi}$ & $1992.95(10)$ \\
\hline space group & $P 2_{1} / \mathrm{c}$ \\
\hline Z & 2 \\
\hline $\mathrm{D}_{\mathrm{c}}, \mathrm{g} / \mathrm{cm}^{3}$ & 1.461 \\
\hline $\mathrm{F}(000)$ & 916 \\
\hline$\mu, \mathrm{mm}^{-1}$ & 0.534 \\
\hline Crystal dimensions, $\mathrm{mm}$ & $0.38 \times 0.33 \times 0.20$ \\
\hline Radiation & $\operatorname{MoK} \alpha, \bar{\lambda}=0.71073 \AA$ \\
\hline temperature, $\mathrm{K}$ & $100(2)$ \\
\hline total data collected & 24711 \\
\hline absorption correction & Semi-empirical from equivalents \\
\hline unique data & $4085\left(R_{\mathrm{int}}=0.0200\right)$ \\
\hline unique observed data $[\mathrm{I}>2 \sigma(\mathrm{I})]$ & 3846 \\
\hline refinement method & Full-matrix least-squares on $\mathrm{F}^{2}$ \\
\hline final $R$ indices $[\mathrm{I}>2 \sigma(\mathrm{I})]$ & $R_{1}=0.0275, w R_{2}=0.0783$ \\
\hline final $R$ indices (all data) & $R_{1}=0.0293, w R_{2}=0.0799$ \\
\hline
\end{tabular}


Table 2

Selected Bond Lengths and Angles for for [Fe(TPP)(TMSO) $)_{2}$.

\begin{tabular}{|c|c|c|c|}
\hline Bond & length(̊̊) & bond & length $(\AA)$ \\
\hline $\begin{array}{l}\mathrm{Fe}(1)-\mathrm{N}(1) \\
\mathrm{Fe}(1)-\mathrm{S}(1) \\
\mathrm{S}(1)-\mathrm{C}(4)\end{array}$ & $\begin{array}{r}2.0020(11) \\
2.2220(3) \\
1.7981(14)\end{array}$ & $\begin{array}{r}\mathrm{Fe}(1)-\mathrm{N}(2) \\
\mathrm{S}(1)-\mathrm{O}(1) \\
\mathrm{S}(1)-\mathrm{C}(1)\end{array}$ & $\begin{array}{l}1.9956(11) \\
1.4794(11) \\
1.8076(15)\end{array}$ \\
\hline angle & value $\left(^{\circ}\right)$ & angle & value $\left({ }^{\circ}\right)$ \\
\hline $\begin{array}{l}\mathrm{N}(2)-\mathrm{Fe}(1)-\mathrm{N}(1) \\
\mathrm{N}(2)-\mathrm{Fe}(1)-\mathrm{S}(1) \\
\mathrm{O}(1)-\mathrm{S}(1)-\mathrm{C}(4) \\
\mathrm{C}(4)-\mathrm{S}(1)-\mathrm{C}(1) \\
\mathrm{C}(4)-\mathrm{S}(1)-\mathrm{Fe}(1)\end{array}$ & $\begin{array}{r}90.55(5) \\
90.63(3) \\
106.54(7) \\
91.76(7) \\
115.18(5)\end{array}$ & $\begin{array}{r}\mathrm{N}(1)-\mathrm{Fe}(1)-\mathrm{S}(1) \\
\mathrm{O}(1)-\mathrm{S}(1)-\mathrm{Fe}(1) \\
\mathrm{O}(1)-\mathrm{S}(1)-\mathrm{C}(1) \\
\mathrm{C}(2)-\mathrm{C}(1)-\mathrm{S}(1) \\
\mathrm{C}(1)-\mathrm{S}(1)-\mathrm{Fe}(1)\end{array}$ & $\begin{array}{r}87.62(3) \\
118.91(5) \\
106.57(7) \\
107.22(10) \\
114.27(5)\end{array}$ \\
\hline
\end{tabular}




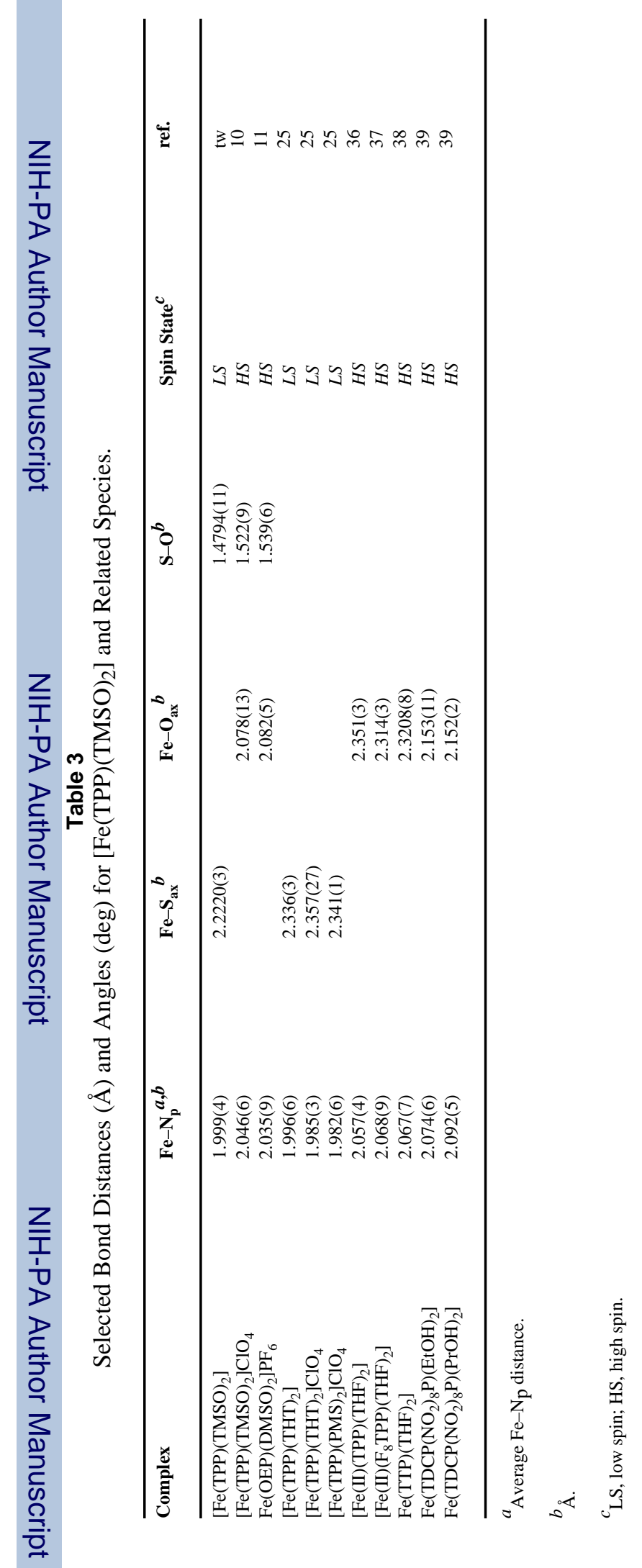

